\title{
Notes
}

\author{
Ben Parsons and Bas Jongenelen
}

\section{"The Sermon on Saint Nobody": A Verse Translation of a Middle Dutch Parodic Sermon}

During the medieval and early modern periods, the mock sermon was one of the most widely staged festive rituals. There are records of its performance in most European countries and cultures. But despite its clear popularity in England, few of these texts are extant in English. Fewer still have been translated in their entirety. To remedy this situation, we provide here a translation of the sixteenthcentury Dutch poem Spotsermoen over Sint Niemand. This piece embodies most of the key features of the mock sermon; the text's rhetorical strategies, its content, and the details it reveals about its performance are all typical of the genre. Thus, the poem is offered as a specimen of the mock sermon's overall conventions and forms.

The following text is a translation of the Middle Dutch Spotsermoen over Sint Niemand (Mock sermon on Saint Nobody), a sixteenth-century parody of contemporary preaching practices. While this piece does have merit in its own right and raises some interesting questions about the genre's form, it is probably most valuable as an example of a fruitful and enduring tradition in European popular culture. The sermon joyeux (mock sermon) was widely practiced throughout medieval Europe. There are numerous surviving examples in Latin, French, Portuguese, Dutch, Spanish, and German (Lehmann 1922:231-2; Koopmans 1988; Revah 1949:19-21; Green 1968:45-7), and its performance in England is recorded from as early as circa 1320 (Meyer 1877). As a custom, the mock sermon has proved remarkably enduring. Unlike other forms of medieval liturgical parody, such as drinker's masses and mock litanies, it persisted well beyond the Reformation, modifying itself to reflect changes in preaching modes (Gilman 1974:31-50). Its importance is also registered in other areas of culture, as it had a powerful and wide-ranging influence on literary composition. Echoes of the form

Ben Parsons is a teaching fellow in English Language at the University of Leicester

BAS JONGENELEN is an instructor in Dutch Literature at the Fontys University of Professional Education, Tilburg, the Netherlands 
have been detected in a number of key medieval and modern texts, such as Jean de Meun's section of the Roman de la Rose (Patterson 1992:331-3), Chaucer's Prologue of the Wife of Bath (Patterson 1991:304-7), Shakespeare's Twelfth Night (Astington 1994:33-5), and Molière's Dom Juan (Bourqui 1992:78). Its influence even seems to extend to such twentieth-century pieces as Samuel Beckett's Waiting For Godot (Kern 1982:32-3) and Charlie Chaplin's The Pilgrim (Perez 2000:115).

Nonetheless, despite its prominence and longevity as a festive form, the mock sermon has received comparatively little attention from English-language scholars. As Jan Hokenson has recently observed, it is among a range of comic forms that "are rarely noted at all" in critical discussions or else are treated in a merely incidental fashion (2006:148). In fact, there has not been a sustained engagement with the tradition since Sander Gilman's survey in the early 1970s. Undoubtedly, one of the main reasons for this neglect is the paucity of sermon texts in English. There are few surviving examples from medieval or early modern England: although it is clear that mock sermons were performed widely in the country from the fourteenth to the eighteenth centuries, only one piece composed before 1600 is now extant (Jones 1997). Moreover, few sermons joyeux in other European languages have been made available to English readers. While several French and German texts have been published in modern editions, such as those of Jelle Koopmans (1984, 1988), William Heist (1968), and Johannes Bolte (1896), none of these have been translated in their entirety. Our translation is therefore offered as a corrective to this unfortunate deficiency. It is intended to make a specimen of the form accessible to commentators working in English, as an illustration of the overall conventions of the genre.

"The Sermon on Saint Nobody" is preserved in a single manuscript copy, which dates from about 1550. It is part of an extremely rich tradition of burlesque in the medieval Low Countries. As Hinke van Kampen observes, parody was a major component of Dutch-language culture throughout the period:

Zoals elk maatschappelijk verschijnsel van enige betekenis in de late middeleeuwen is ook dit aangegrepen voor parodie. ... De populaire drukpers heeft veel van zulke spot- en speelteksten ... voor een zo breed mogelijk publiek. ... Er gaat een sterk sociaal effect uit van deze vrolijke boekjes.

[It seems as though every social phenomenon of any importance in the late Middle Ages was claimed for parody... The popular printers produced many such parodies and play-texts, which attained a large readership... These playful works had a strong social impact.] (van Kampen et al. 1980:5)1

In fact, the prevalence of such practices seems to have been a source of cultural pride in the early modern Netherlands. In The Praise of Folly, Desiderius Erasmus's own contribution to parodic literature, Stultitia praises "Hollandi mei" (my Hollanders) because they are "usque adeo studiosos mei cultores, ut inde uulgo cognomen emeruerint, cuius illos adeo non pudet, ut hinc uel praecipue sese iactitent" (so devoted to my worship that they have commonly earned the nickname of fools, which they are not ashamed of, but even use among themselves; Erasmus 1991:11). Accordingly, Middle Dutch has preserved a large corpus of zotte teksten (texts of foolery). 
This group in turn contains around ten spotsermoenen (Kaijser 1983-4), along with numerous monologues that overlap with the form, sharing its general sensibility or design (Coigneau 1980-3; Hüsken 1987; Pleij 1985).

Even though parodic literature attained a particular prominence in the Low Countries, its forms were by no means specific to this region. It would be a mistake to regard medieval Dutch comic literature in strict isolation, since its constituent topoi and frameworks were themselves part of a Europe-wide culture. In the case of the mock sermon, this is particularly important, since the form is deeply rooted in medieval festivity more generally. The strategies it employs to ridicule its target, for example, are those used in many inversion rituals. For example, the sermon systematically inserts carnal or earthly images into the structures of higher discourses and practices. Thus, it recounts a funeral procession in which the dead man is carried on a muck-cart and buried in a pigsty, and it treats drinking and sex as alternative sacraments. At various points, it advises the audience that "the kingdom of Heaven shall open to you / If you drink yourself mad," and it assigns particular duties to the women in the crowd: "You women, and also your daughters / . . f fill up your bodies with the stuff we pour / Or else you'll be virgins for evermore" (lines 16-7, 156-9). There are also repeated references to the anus in the context of learning, as the speaker fears that his hearers will lose their memory of the sermon through this orifice (line 12). As well as recalling carnival, with its general "transfer of every high ceremonial gesture . . to the life of the belly and the reproductive organs" (Bakhtin 1984:20-1), these reversals are quite typical of the sermon joyeux as a genre. In its use of these devices, "Saint Nobody" bears comparison to the French Sermon du ménage et des charges de mariage (Sermon on the household and the cost of marriage), in which the preacher refers to his "scripture" in similarly alimentary terms:

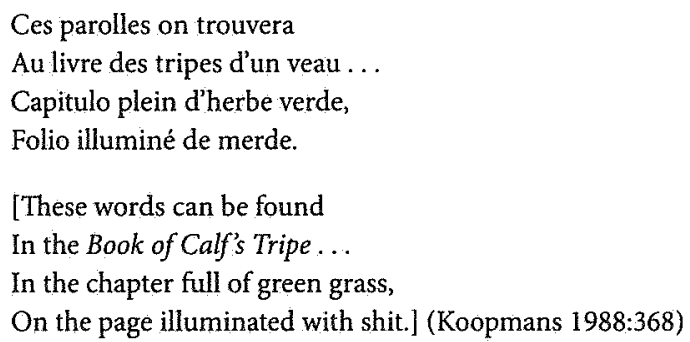

The other Dutch spotsermoenen are also replete with this form of humor. One includes the oath "steckt nu al u vingeren int gat en custse dan" (now stuff your fingers into your hole and kiss them; Pleij 1979:252). Comparable material also occurs in the earliest surviving example of the genre, the fragment Dit es van den scijtstoel (This is from the shitting-stool), dating from about 1500 . The title of this piece substitutes preekstoel (preaching stool) for a more excremental equivalent. By referring to dirt and drunkenness in a devotional context, "Saint Nobody" is following a key stratagem of the sermon joyeux as a genre.

However much it may debase the idioms and techniques of homily, the structure of "Saint Nobody" nonetheless closely follows late-medieval preaching convention. By the late Middle Ages, sermons came to be governed by a strict framework, largely in response 
to the "scholastic discipline" of the universities, with its emphasis on "systematic analysis" and "definitions and marshalling" of evidence (Lawrence 1994:120-1). Hugh Oliphant Old provides a helpful summary of this usual sermon form:

The convention of the thema and prothema became characteristic.... Together the two served to introduce the sermon: the thema announced the text, and the prothema, by means of introducing a second text, spoke of the significance of the text for the listener. The prothema then moved on to an invocation of divine help for the preacher and the congregation, frequently asking the congregation to recite the Ave Maria or the Pater Noster. .. A peroration concluded the message. (Old 1999:299)

The mock sermon presented here faithfully maintains this sequence. The gibberish Latin with which the piece commences (lines 1-6) provides it with a thema. A vernacular "translation" of this is supplied later on, even though this does nothing to disclose the contents of the Latin (line 15). The prothema is then invoked, as the preacher recounts the story of a man "drinking until he burst," allegedly taken from capito nullo (chapter nothing) (lines 23-4). This has the purpose of moving the "message" of the sermon from general to specific terms, as the unfortunate drinker comes to stand as a direct "example" for the congregation to follow: they are invited to "think of the bliss that was his to sample" (lines 29-30). There are also intermittent calls for prayer, albeit with a clearly abusive intent: "My brethren, kneel down and join me in prayer / For clerics and laymen everywhere: / May they have long life, in tremendous pain" (lines 102-4). The final lines then give a compact instruction to the listeners, one that effectively summarizes the preceding arguments and returns to their theme and to central "authorities." In spite of its stylistic excesses, therefore, the text remains firmly within the overall schema of the late-medieval ars praedicandi (art of preaching). Its formal aspects are tightly regimented, in contrast to its boisterous and unbridled subject matter. This close imitation is once again typical of the mock sermon as a whole. As Gilman notes, the entire "basis for parody" in the genre lies in creating a "contrast between the idealized sermon form and the actual sermon, between the literary and rhetorical structure" (1974:9). Eli Rozik draws a similar generalization, noting that "the mock sermon parodies its model" by rigorously upholding "its way of reasoning" (2002:220).

"Saint Nobody" is no less typical in its actual content. The undoubted centerpiece of the text is its description of the "holy man" Saint Drincatibus, who is in reality little more than a drunken derelict. The text describes in great detail how Drincatibus would drink until he became incontinent, presenting such habits in terms borrowed from martyrology:

He drank so much, many authors admit,

That daily he filled his pants with shit

He often lay in filth - true hardship he knew-

And when he stood it ran out of each shoe. (lines 82-7)

This again follows the usual course of mock sermons, both before and after the Reformation. Many of the surviving texts make the lives of saints particular targets for 
ridicule, with nine of the thirty-one French texts incorporating some form of parodic hagiography (Merceron 1998:335-6). In fact, Charles Livingston characterizes the form as a whole as an "irrévérentieuse caricature d'une vie de saint" (an irreverent caricature of the saint's life) (1951:130), while Koopmans and Paul Verhuyck list parodic hagiography among the "principaux themes" of the literature (1987:14). The Dutch piece openly ties itself to its precedents by claiming to recount the life of Saint Nobody. Although sint Niemand only appears in the title of the piece, the mere fact that his name is invoked is significant. The figure of Saint Nobody first appears in the thirteenth-century Historia de Nemine, which is in many respects the prototype of all later mock hagiography. This is not in fact a mock sermon at all but an academic exercise with its roots in medieval exegesis (Bayless 1996:79). The Historia gathers instances of the word nemo (nobody) from scripture and patristic sources and assembles them to form a biography for this "holy man" (Lehmann 1922:240): thus it reports that Nemo was honored by Jesus, who ordered his followers to "salute Nobody by the way" (Luke 10:4), and declares that he is immortal, since Ecclesiastes 9:4 attests that "Nobody liveth forever" (Denifle 1988:345-6). Even though such learned word games are quite far removed from the vernacular mock sermons, as Ian Russell (1989) in particular has observed, Nemo was drawn into the sermons joyeux from an early date. Here he comes to ridicule saint's lives in general, as various improbable deeds are attributed to the figure (Calmann 1960:61). The Dutch sermon's allusion to Nemo, even though Drincatibus is its real focus, situates it squarely in this tradition.

In terms of its performance, the actual occasion for presenting "Saint Nobody" is fairly clear. The time of year when the sermon was performed can be readily deduced from internal evidence. It seems most closely linked to the pre-Lenten festival known as Vastenavond in the Netherlands and Shrovetide in England, which the text refers to as "this holy week" (line 61). This is apparent from the prayer it offers to unfortunate captives, who will apparently "not be spared" in a few weeks' time (line 107). Urging the congregation to pray for these wretched prisoners, the sermon goes on to name them as "Peter Ox, Gerald Goose, / Giles Rabbit, John Capon, Peter Sheep" (line 10910). Later it gives a similar list, this time of people who will supposedly claim shelter in all homes over the next few weeks: it cites among others "Peter Mullet, John Hake, Matthew Mackerel" (line 135). In other words, the sermon is paying an ironic tribute to a series of foodstuffs. What makes this litany significant is its clear seasonal implications. As Herman Pleij states, this "ludicrous list of personifications of food" refers to meat proscribed during Lent on the one hand and the fish that can legitimately be eaten on the other: it includes "some... which would not appear on the table till Easter and some that either should or should not be served during the coming Lenten fast" (Pleij 2001:148). Since the sermon is anticipating the "banning" of some of these figures and their eventual devouring at Easter, it was evidently composed for Shrovetide celebrations. The overall emphasis on penance and confession, albeit with such impious recommendations as "you free a soul from purgatory with each glug," would also be consistent with this point in the festive calendar (lines 48-9). This setting is again not unusual for the mock sermon (see Gilman 1974:24-5). Another Dutch text, the Mandement van Bacchus (Commandment of Bacchus), explicitly attaches itself to Vaste- 
navond. Parodying the language of sermons and official proclamations alike, the Mandement specifies that Bacchus is overlord until mid-February, the date at which Lent commences (Pleij 1979:253-5). The device of offering prayers to food is also common. One French example, Le Sermon joyeux de Saint Jambon et de Sainte Andouille (The sermon of Saint Ham and Saint Sausage; see Koopmans 1984:47-56), develops this even further, describing the "martyrdoms" of its titular "saints," as they are "salted, hung, boiled or roasted, cut into slices and finally eaten" (Jeanneret 1991:205). This idea also occurs in the Middle Dutch Legende van Sinte Haryngus, which similarly recounts the passion of "Saint Herring" (De Vreese 1922). Several other sermons joyeux therefore share the pre-Lenten context of "Saint Nobody" as well as its focus on proscribed or permitted meats.

It should be noted that the mock sermon in general was by no means confined to Shrovetide alone. Christmas also provided an opportunity for the custom to be exercised. The Dutch "This is from the Shitting-stool" is evidently connected to the winter festivities. Its focal saint is one Snottolf (Snot-nose), who functions as a sort of personification of winter's effects on the human body. It also contains meditations on the efficacy of using goeder tsne vlocken (good snowflakes) to clean one's ertsgat (asshole), which again locates it firmly in the winter (Biemans et al. 2000:162-4). Much the same is true of the English mock sermons, which also contain unmistakable links to Yuletide. A key example is The Exaltation of Christmas Pye (1659), a sermon intended "to discredit Puritan antipathy towards religious festivals" by "burlesquing the Nonconformist preacher" (Thomas 1969:202). Nonetheless, even beyond these two festivals, the sermon had a presence elsewhere in the ritual year. There was in fact barely an occasion for festivity that did not come to include mock sermons. The feast of the Holy Innocents (Chambers 1903, vol. 1:380-1), Plough Monday (Davidson 1998:67), and various occasional celebrations could also play host to these parodies.

Although it is clear when "Saint Nobody" was primarily performed, the manner of its performance is a little harder to establish. The text itself gives few indications of how it ought to be enacted. However, a number of other sources do give a fairly good impression of how mock sermons were most likely staged. Perhaps the fullest of these accounts is Thomas More's Confutation of Tyndale's Answer ([1532] 1973). Since More was himself involved in organizing the Christmas revels at Lincoln's Inn, his comments have a high degree of authority (Jones 1997:95). At one point in his tract, More ridicules his Protestant opponents by comparing them to "a sort of freres folowynge an abbote of mysrule in a Christemas game" (a sort of friar following an Abbot of Misrule in a Christmas game). He then goes on to give an enlightening description of how such figures customarily behave: they "were prykked in blankettes, and then sholde stande vp and preche vppon a stole and make a mowynge sermon ... fyrst gapeth \& then blesseth, and loketh holily and precheth ribauldrye to the people yt stand about" (were dressed up in blankets, and then will stand up and preach upon a stool and make a mocking sermon ... first he insults and then blesses, and looks holy and preaches ribaldry to the people that stand about; 1973:919). While the costume described in this passage has a clear deflationary function, replacing official vestments with mundane domestic equivalents, it is also markedly simple. This in 
turn makes the parody appear very easy to stage. Since only a small collection of common items were needed to enact it successfully, the sermon requirêd little in the way of special equipment or preparation (Jones 1997:95-6).

This point is further borne out by a description of the genre from eighteenth-century Massachusetts. The conventions of the parodic sermon seem to have been imported with little alteration to the Americas. As James West has documented, the form enjoyed a particular vogue in the 1840s (1978:209-18), and no less a figure than Herman Melville produced his own "Short Patent Sermon" in 1847 (Melville 1995:443-4). One record of a sermon performance at Boston seems if anything even more makeshift than Mores "mowynge sermon." On Shrove Tuesday 1712, it is reported that "at Ephraim Savage's tavern, one of the company donned a clerical gown and delivered a mock sermon full of monstrous profaneness and obscenity" (Brown 1989:40). Again, there is a rudimentary, semi-improvised quality to the sermon, as it involves one of a group pulling on a simple costume and speaking in a public place. Even more ad hoc is the Sermon on Malt, attributed to the minister John Dodd (c. 1555-c. 1645). Dodd was apparently waylaid on the road to Cambridge by a group of local students and made to deliver "an extempore sermon ... in a hollow tree which stood by the road side ... from a text they should choose" (Oldham 1853:118-9). As such sources indicate, the performance of mock sermons could be an elementary, almost impromptu affair.

This is not to say that all mock sermons were performed in such a simple or strippeddown manner. Other witnesses suggest that the tradition had the potential to be a much more complex spectacle. An account from sixteenth-century Germany shows how the sermon could be incorporated into a relatively elaborate setting. In 1524 at Buchholz, an entire parodic procession was staged: a collection of "relics" were paraded through the town, consisting of "a horse's head, the jawbone of a cow and two horselegs," all loaded on a muck-cart and drawn "to an old mine shaft preceded by a fiddler." The procession itself included further burlesque elements, such as "banners made of rags," "gaming boards for songbooks," "dung forks for candles," "participants wearing sieves and bathing caps in parody of canon's berets," and "a mock bishop dressed in a straw cloak, with a fish basket for a mitre." The whole affair culminated in the recital of a mock sermon on "the holy arse-bone of that dear canon of Meissen St Benno" in the market square (Scribner 1987:74). The sermon here takes place on a much wider scale than More's preaching of "ribauldrye." It is part of a substantially larger performance, in which the entire town seems to be involved in some measure. The French sermons joyeux also attain a comparable scope. Several of the texts occur within larger dramatic productions, as they introduce a farce, are recited by a character within it (Picot 1886:358-9), or else appear in the context of a wider celebration. As Chambers writes, the French sermon often found "its place in the general burlesque of divine worship," staged "upon a scaffold near the church door" or among other "jeux in the streets" (1903, vol. 1:381). Again, the pieces are staged as part of a more expansive spectacle, in which more than a single figure is involved. The extensive use of props in the German event is also mirrored by other English reports of sermons. An account of a Lincolnshire mock preacher of 1601, for instance, describes the figure standing "in a thinge of wainscott [wooden paneling] made like a pulpitte ... fixed to the maypole," and keeping a "pott of ale or beare [beer]" by him "in steade of an hower glasse 
[hourglass]." This last item was apparently used to demarcate the sections of his sermon, as the preacher "did Drinke at the concluding of any poynte or parte of his speech" (O'Conor 1934:120).

"The Sermon on Saint Nobody" seems to fall midway between these extremes of simplicity and embellishment. On the one hand, it demands only a basic mode of performance. It does not seem to require any special accompaniments and does not include any participants beyond its orator: at least no reference is made to any devices or instruments, and no lines are allocated to other speakers, in the manner of other Dutch monologues of the period (Jongenelen and Parsons 2008:475). Specific details also align the text with the more modest types of performance. Like the Bostonian example quoted above, the sermon seems designed to take place in a tavern rather than in a larger public space. At several points, the poem refers to its occurrence within a ledegher kercken ("empty church," in the sense of "frivolous" or "vain"; lines 146,66$)$. This probably exploits the common medieval conceit of the tavern as a sort of anti-church: as one fifteenth-century author puts it, "pe tauerne is welle of glotonye, for it may be clepyd ... pe deuelys chapel, for pere his dyscyples stodyen and syngyn, bothe day \& nyht, \& pere pe deuyl doth meraclys to his seruauntys" (the tavern is a well of gluttony, and it may be called the devil's chapel, for there his disciples study and sing, both day and night, and there the devil does miracles for his servants; Brandeis 1900:147). By referring to its venue in such terms, the text evidently locates itself in a tavern. The fact that it also encourages the audience to sleep in "this church" rather than "in a barn in the cold night air" only reiterates this point (line 155), again implying that the sermon was originally recited at an inn. Such a locale is obviously better suited to simple rather than elaborate staging. Unlike the German or French examples, which took place in market squares or streets and could therefore integrate more complex elements into their execution, this mock sermon is a smaller event intended for a more enclosed space.

Even though "Saint Nobody" seems fairly humble in terms of performance, there is some suggestion that the spotsermoen did use props of some sort. The reference to "pardons heaped up here" in line 149 is interesting. There is a possibility that this simply refers to beer, in keeping with its tavern setting and its general characterization of drinking as a form of penance. Earlier, the poem suggests that alcohol can function as an indulgence, asserting that "he who drinks till he dishonors his trousers / Will receive absolution aplenty" (lines $51-2$ ). However, what makes this reading problematic is the fact that the congregation is specifically warned not to "disturb the pardons" (line 149). This contradicts the general thrust of the piece, with its counsel to "drink yourself mad" (line 17). It may therefore be possible that the preacher has some mock pardons to distribute to his listeners, rather like the "certain papers" given out by the Lords of Misrule who presided over Midsummer festivals, "wherin is painted some babblerie [crude emblem] or other of Imagery woork" (Stubbes 1882, vol. 1:148). The performer might well have ended his homily by disseminating these documents to the crowd, and they may have offered the paradoxical absolution he describes in his sermon (see line 53). Such behavior is certainly not without parallels. It is clear that some mock preachers did circulate items to revelers. In David Lindsey's play Ane Satyre of the Thrie Estaitis ([1552] 1989), for instance, the character Foly gives out 
"meat" and "folie hattis" (folly hats) before delivering a satirical sermon on the theme of Stultorum numerus infinitus (the number of fools is infinite; Lindsey 1989:155-7). There are also numerous references to mock preachers carrying indulgences. The speakers of French sermons joyeux often advertise the fact that they have "pardons generaux" (general pardons) with them, using this as a pretext for lurid "enumeration of categories pardoned for their sexual misdemeanours" (Burrows 2005:97). It therefore seems at least possible that the performer of "Saint Nobody" had a stock of parodic pardons with him, to issue to his audience at the conclusion of his speech. Even though the text requires only a very basic performance, it may have incorporated simple props.

Beyond these pieces of evidence, perhaps the most important thing that the text reveals is the deep-rooted conservatism of the mock sermon. Although the great nineteenth-century scholar Gaston Paris may have been "astonished" by the "audacity and freedom" of the sermons joyeux, "Saint Nobody" demonstrates that a conventional, even didactic element is at the heart of these parodies (1903:160). Beneath the surface ribaldry and disorder of the piece, with its copious allusions to feces and dissipation, there is a clear constructive purpose at work. This can be seen in the inversions that "Saint Nobody" carries out, which often have a clear moral dimension. Throughout the piece, virtue and sin - and even good and evil-are made to exchange places. At one stage, the text describes the spirit of a dead glutton "dressed in black" and sent to dwell "in darkness," although it insists that the man was "an angel" and promotes him as a model for devotion (line 26). The system of divine punishments and rewards is also reversed: the listeners are instructed "Always drink freely should the chance arise / And your soul will find its way to paradise" (lines 21-2). Even the motives of the preacher himself are implicated in this inversion. At one stage he pleads for money from the assembled, although he reveals that this is not for charitable ends but to pay off a prostitute who "accosted me just now, outside the door" (line 125). The sermon not only inverts the usual hierarchy between souls and bowels but also extends this policy to behavioral codes as well. In other words, it does not merely overturn the gestures and symbols of the sermon but seems to capsize the values at its center, replacing them with its own parodic ethos.

By implementing this process, the text only reconfirms the authority of conventional morality. The sermon's moral reversal in fact serves to undermine the debauchery that its preacher seems to advocate. This is particularly apparent in the text's continual play with the theme of nothingness. Not only does it characterize its setting as an "empty church," but the "scriptures" it evokes are all similarly negated. When citing its authorities, it refers to "chapter nothing" and the "Book of Nothing," and it bases its arguments on texts that "have not been written" (lines 1,23,14). This is strikingly at odds with the behavior often ascribed to medieval festivity. Bakhtin's carnival, for instance, always "has a positive, assertive character" and founds itself on "fertility, growth, and a brimming-over abundance" (1984:19). Against this conception, "Saint Nobody" roots itself in absence rather than substance and nonexistence rather than plenitude. Accordingly, these various moves have the result of stifling any sense of carnivalesque upheaval, canceling the "unofficial point of view" that Bakhtin describes (1984:41). They succeed instead in enshrining accepted morality, dispelling 
the sermon's message even as it is issued. By identifying its voice with emptiness and defining its authorities in negative terms, the sermon is presenting itself as a fiction devoid of any real content. It characterizes itself as something fundamentally hollow, as its speaker and his discourse have literally no underlying essence, with nothing to disclose or offer. This means that the alternative morality the sermon seems to proclaim is granted no real being of its own. What appears to be a possibility beyond common standards is presented only as a lack. The sermon thus refers its audience back to the normality it seems to attack. There is literally nothing beyond accepted convention, as even this apparent break with the status quo turns out not to exist, having no being of its own. Ultimately, although "Saint Nobody" impersonates an instructive speech, it only serves to discredit the code it describes. It follows Peter Dronke's general description of medieval parodic literature, as its "mocking fantasy $\ldots$ is teased out in detail as though it were reality ... and yet - this is essential to the fantasy-the Christian God and his cult remain" (1982:584). In spite of its scurrilous and often repulsive subject matter, the spotsermoen retains at all times a deep-seated moral sensibility. It actively emphasizes the validity of the framework it appears to uproot and destroy.

\section{Notes on the Translation}

Our translation is based on the edition of Spotsermoen over Sint Niemand included in Herman Pleij's collection of parodic texts (1979:256-9). It is, to our knowledge, the first time that this text has been translated into English. The line numbers of the translated text follow those of Pleij's edition. The original text is written in a rough, doggerel-style meter, which we have endeavored to re-create as closely as possible.

\section{"The Sermon on Saint Nobody"}

Non scriptum est in libro Nullorum

De uno Nullo Willecommorum

Capitulorum nullo decimo sexto.

Ille Nullus nonfuit curates

5 Nec etiam magistratus

In nullo prolegeorum.'

Dreary beloved, gathered here today, ${ }^{3}$

I pray listen well to all I have to say.

These words come from Latin: you must take care

10 To study the wisdom that they lay bare.

Imprint them on your very heart and soul,

In case they leak out through your asshole,

Because they reflect the noblest of men.

Without the aid of paper, ink, or pen,

15 He left us a message, honest and true:

The kingdom of Heaven shall open to you

If you drink yourself mad. I will interpret:

My brethren, lest your soul be forfeit,

Don't hoard up your goods for a rainy day,

20 Even if your children should waste away, 
Always drink freely should the chance arise And your soul will find its way to paradise. We read in capito nullo of a thirst That caused a man to drink till he burst.

25 What did he look like, you wish to know? Like all angels-dressed in black, from head to toe. I read that his soul then flew, quick smart, To Heaven, to dwell in its darkest part. Think of the bliss that was his to sample.

30 Children, let this man be your example, From the scourge of light you will be freed. Do it now, not later. I pray, take heed.

Non scriptum est in libro Nullorum

De una Nullo Willecommorum

35 Capitulorum nullo decimo sexto.

Saint Drincatibus speaks of the holy ground, Where the tomb of Nullus Willecomme is found, So widely admired, as everyone knows, That all doors were slammed shut on his nose,

40 From every corner with no drink he was plied. Children, may great gulps down our throats slide: In this duty Nullus never fell short.

From his tomb indulgences may be bought, A plena culpa $a^{5}$ can be yours for a song.

45 From this point I shall try to hold my tongue And to return to the theme of my speech: Only drinking will put Heaven in reach. Drink till you're cross-eyed, from your wine or beer jug, You free a soul from purgatory with each glug.

50 Listen to what Drincatibus espouses: He who drinks till he dishonors his trousers Will receive absolution aplenty,

Forty days of grace, minus two times twenty, With as many pardons as he is due.

55 If you doubt this, the Pope will curse you. So make sure your absorptions are kept up, This summer you must fill and drain your cup Even if your cash should escape clean awayNot even that will keep scumbags at bay. ${ }^{6}$

60 Heed my words! There is good in all I speak, Redemption can be yours this holy week. All that I say now is no ploy or jest: After tonight come eight nights without rest. I urge you to be joyful in spirit,

65 And to pay these three churches a visit: They are empty, so therell be room, don't fear. Then I will give the best command you'll hear To drink a certain water, three mugs or four. Even if your asshole starts to pour

70 Ignore it, as long as your ribs are full. You may wake with cellar fever in your skull, But this precious liquid you must revere: It has traveled seven miles to be here. 
Saint Drincatibus, that devoted soul,

75 Was the first who tipped it down his neck-hole.

He lived with Bacchus, a man holier still,

Who taught him to drink without reaching his fill.

He drank so much that all sin he forgot,

And then at the last he choked on his snot.

80 This killed him dead, as the scripture makes plain,

Not as a saint, but as a martyr to pain.

He drank so much, many authors admit,

That daily he filled his pants with shit.

Think of the trials this man had to endure,

85 With his asshole running wet with ordure.

He often lay in filth-true hardship he knew-

And when he stood it ran out of each shoe.

Does this mystery not move your heart?

Alas! They laid him on a muck-cart.

90 No one would undress him, no one even tried,

Since he was caked in shit on each side.

His corpse fell on the ground, exposed to all, Snotty, shitty, covered in spittle and gall.

Some women dragged him to a pigsty,

95 They pulled a handkerchief out of his fly,

And gave it to stray cats for their dinner-plate.

Women! Do you see the suffering you create?

Think about the evils you have performed!

That poor wretched saint lies there all deformed,

100 As if he was dredged out of a cesspool.

Thus he was martyred, from your treatment cruel. My brethren, kneel down and join me in prayer For clerics and laymen everywhere:

May they have long life, in tremendous pain.

105 Now I shall ask you to pray once again For those held prisoner this Ash Wednesday, Since they will not be spared either way, And their souls must certainly be let loose. Hear their names: they are Peter Ox, Gerald Goose,

110 Giles Rabbit, John Capon, Peter Sheep.?

Sadness into their poor hearts shall creep As they try to open every lock and bolt. All who go to slaughter, through goodness or fault, From Ash Wednesday to Easter are disallowed.

115 So raise your voices for them, clear and loud: May they make their way to a hungry gut. In the name of charity, your purses I must cut, For a poor sick boy, Martin Fields by name. His house contains such lack it is a shame.

120 All his maid found in his pantry yesterday Was a dead mouse that had wasted away. There is another case I must mention, Though I blush to bring it to your attention I feel compelled. It is Gilly Youngwhore.

125 She accosted me just now, outside the door. The young men seem to like her well enough, 
So please give freely, then I can pay her off.

She has secret hardships, in no small amount.

Well, now I am forced to give an account

130 Of those we will host till Easter comes around,

In each house at every hour they'll be found.

I shall name them all, since I feel daring:

There is John Cod, Peter Haddock, John Herring, ${ }^{8}$

Gerald Kipper, Giles Halibut as well,

135 Peter Mullet, John Hake, Matthew Mackerel,

At the fireside they have a special bench.

Then there is Lance Carp and Finley Tench,

George Salmon, John Pilchard. Even when ill,

Even in bad times, you'll shelter them still:

140 Until Easter comes, each one is our guest.

A number of women must also be addressed,

Such as Gretchen Greasepan and Claire Olivetwig,

Claire Apple, Betty Raisin, Trudy Fig.

Countless others into our kitchens will crawl,

145 There are so many I can't count them all.

In this empty church, hear now my commands:

For four days you may rest your feet and hands,

Then in this empty place you must reappear.

Do not disturb the pardons heaped up here.

150 Although they may be false and incorrect

You fools must show them proper respect,

Because there is nothing that is much worse

Than finding yourself placed under a curse.

This church warns masters and boys to take care

155 Not to sleep in a barn in the cold night air.

And you, women, and also your daughters,

Must visit this empty place, take its waters,

Fill up your bodies with the stuff we pour

Or else you'll be virgins for evermore.

I60 Absolvat vulgat, or "your ass will start gushing":"

A saying of Drincatibus, patron of nothing,

You may reach where he lies, if you're imprudent.

Bacchus once gave a blessing to his student

(This is the last I shall say of these two)

165 That same blessing I now pass on to you:

May your shirt be wet at front and back too.

Amen.

\section{Notes}

1. Unless otherwise stated, all translations are our own.

2. This section parodies a part of the conventional sermon form called the thema (see our discussion above). The text consists of garbled Latin, interspersed with snippets of Latinized Dutch. Its meaning may be loosely translated as follows: "It is unwritten in the Book of Nothing of one Nullo Willecommorum [Welcome-To-Nobody], in the nothing-and-sixteenth chapter. This Nullo was not a priest, and nor was he a teacher, in nothing of a prologue." This recalls Mores description of the mock preacher basing his "mowynge sermon" on "some fonde textes [silly sayings] of his own hed [i.e., of his own inven- 
tion]," rather than "medl[ing] wyth ye very scrypture yt selfe" (interfering with the true Scripture itself; 1973:919).

3. In the original Middle Dutch, this line is "Ongheminde vriendekens overal." Translated literally, it reads "Unbeloved friends everywhere."

4. This phrase translates as "chapter nothing."

5. This translates as "full of fault." It is evidently punning on the phrase "mea culpa" (my own fault), a confessional formula taken from the penitential prayer the Confiteor.

6. These lines seem to parody a passage in Juvenal's Satires (1992), 10:22, which reads: "Cantabit vacuus coram latrone viator" (the empty-handed traveler can rejoice in the presence of the robber). Since the phrase had become a common moral proverb during the Middle Ages (see Whiting and Whiting 1968:266), it is an obvious target for ridicule in this deliberately amoral text. In fact, Gilman specifically notes that traditional adages were often lampooned in mock sermons, especially those performed at Shrovetide (1974:25).

7. The various figures listed here are personifications of foodstuffs prohibited during Lent: hence "from Ash Wednesday to Easter" they are "disallowed" (line 114).

8. Unlike the preceding list, this roll call of fish and vegetable personifications are all part of the acceptable diet during Lent. Thus "until Easter comes, each one is our guest" (line 140), since no other food will be available during the fast.

9. This line contains an untranslatable pun, which relies on the phonic similarity between these two Latin words (absolvat vulgat) and the Middle Dutch "'t avont 't heersgat" (you wet your asshole).

\section{References Cited}

Astington, John. 1994. Malvolio and the Eunuchs. Shakespeare Survey 46:23-35.

Bakhtin, Mikhail M. 1984. Rabelais and His World, trans. Helene Iswolsky. Bloomington: Indiana University Press.

Bayless, Martha. 1996. Parody in the Middle Ages: The Latin Tradition. Ann Arbor: University of Michigan Press.

Biemans, Jos, Hans Kienhorst, Willem Kuiper, and Rob Resoort, eds. 2000. Het Handschrift-Borgloon. Hilversum, the Netherlands: Verloren.

Bolte, Johannes. 1896. Georg Schans Gedichte vom Niemand. Zeitschrift für vergleichende Litteraturgeschichte 9:73-88.

Bourqui, Claude. 1992. Polémique et stratégies dans le Dom Juan de Molière. Paris: Papers on French Seventeenth Century Literature.

Brandeis, Arthur, ed. 1900. Jacob's Well, an Englisht Treatise on the Cleansing of Mar's Conscience. London: Kegan Paul, Trench, Trübner.

Brown, Richard D. 1989. Knowledge is Power: The Diffusion of Information in Early America, 1700-1865. Oxford: Oxford University Press.

Burrows, Daron Lee. 2005. Two Old French Satires on the Power of the Keys: "Lescommeniement au lecheor" and "Le pardon de foutre." London: Legenda.

Calmann, Gerta. 1960. The Picture of Nobody: An Iconographical Study. Journal of the Warburg and Courtauld Institutes 23(1-2):60-104.

Chambers, E. K. 1903. The Medieval Stage. 2 vols. Oxford: Clarendon Press.

Coigneau, Dirk. 1980-3. Refreinen in het zotte bij de Rederijkers. Ghent, Belgium: Secretariaat van de Koninklijke Academie voor Nederlandse Taal-en Letterkunde.

Davidson, Hilda Ellis. 1998. Roles of the Northern Goddess. London: Routledge.

Denifle, H. 1988. Ursprung der Historia des Nemo. Archiv für Literatur- und Kirchen-Geschichte des Mittelalters 4:340-8.

De Vreese, Willem. 1922. De legende van Sint-Haringus. Het Boek 11:299-304.

Dronke, Peter. 1982. Profane Elements in Literature. In Renaissance and Renewal in the Twelfth Century, ed. Robert L. Benson, Giles Constable, and Carol D. Lanham, pp. 569-92. Cambridge, MA: Harvard University Press. 
Erasmus, Desiderius. 1991. Stultitiae Laus, ed. John F. Collins. Indianapolis, IN: Hackett.

Gilman, Sander. 1974. Parodic Sermon in European Perspective: Aspects of Liturgical Parody from the Middle Ages to the Twentieth Century. Philadelphia: Coronet Books.

Green, Otis Howard. 1968. Spain and the Western Tradition: The Castilian Mind in Literature from El Cid to Calderón. Madison: University of Wisconsin Press.

Heist, William W. 1968. Sermon Joyeux and Polemic: Two Sixteenth-century Applications of the Legend of the Fifteen Signs. Chapel Hill: University of North Carolina Press.

Hokenson, Jan Walsh. 2006. The Idea of Comedy: History, Theory, Critique. Cranbury, NJ: Associated University Press.

Hüsken, Wim. 1987. Noyt meerder vreucht. Compositie en structuur van het komisch toneel in de Nederlanden voor de Renaissance. Deventer, the Netherlands: Sub Rosa.

Jeanneret, Michel. 1991. A Feast of Words: Banquets and Table Talk in the Renaissance, trans. Jeremy Whiteley and Emma Hughes. Chicago: University of Chicago Press.

Jones, Malcolm. 1997. The Parodic Sermon in Medieval and Early Modern England. Medium Aevum 66(1):95-114.

Jongenelen, Bas, and Ben Parsons. 2008. "A. Famous and Most Miraculous Prophecy": An Annotated Translation of a Middle Dutch Trickster Poem. Journal of American Folklore 121(482):473-84.

Juvenal. 1992. Persi et Juvenalis Saturae, ed. W. V. Clausen. London: Oxford University Press.

Kaijser, Dick. 1983-4. Het laatmiddeleeuwse spotsermoen. Spektator 13:105-27.

Kern, Edith. 1982. Beckett's Modernity and Medieval Affinities. In Samuel Beckett: Humanistic Interpretations, ed. Morris Beja, S. E. Gontarski, and Pierre A. G. Astier, pp. 26-35. Columbus: Ohio State University Press.

Koopmans, Jelle. 1984. Quatre sermons joyeux. Geneva: Droz.

- ed. 1988. Recueil de sermons joyeux: Édition critique avec introduction, notes et glossaire. Geneva: Droz.

Koopmans, Jelle, and Paul Verhuyck. 1987. Sermon joyeux et Truanderie. Amsterdam: Rodopi.

Lawrence, C. H. 1994. The Friars: The Impact of the Early Mendicant Movement on Western Society. London: Longman.

Lehmann, Paul. 1922. Die Parodie im Mittelalter. Munich: Drei Masken Verlag.

Lindsay, David. 1989. Ane Satyre of the Thrie Estaitis, ed. Roderick Lyall. Edinburgh: Canongate.

Livingston, Charles Harold. 1951. Le jongleur Gautier le Leu: Étude sur les fabliaux. London: Oxford University Press.

Melville, Herman. 1995. The Piazza Tales and Other Prose Pieces, 1839-1860, ed. Harrison Hayford. Evanston, IL: Northwestern University Press.

Merceron, Jacques E. 1998. Obscenity and Hagiography in Three Anonymous Sermons Joyeux and in Jean Molinet's Saint Billouart. In Obscenity: Social Control and Artistic Creation in the European Middle Ages, ed. Jan M. Ziolkowski, pp. 332-44. Leiden: Brill.

Meyer, Paul. 1877. Melanges de poesie francaise, iv: Plaidoyer en faveur des femmes. Romania 6:499503.

More, Thomas. [1532] 1973. The Confutation of Tyndale's Answer, ed. Louis A. Schuster. Vol. 8. of The Complete Works of St. Thomas More. New Haven, CT: Yale University Press.

O'Conor, Norreys Jephson. 1934. Godes Peace and the Queenes: Vicissitudes of a House, 1539-1615. Cambridge, MA: Harvard University Press.

Old, Hugh Oliphant. 1999. The Medieval Church. Vol. 3 of The Reading and the Preaching of the Scriptures in the Worship of the Christian Church. Grand Rapids, MI: Eerdmans.

Oldham, Oliver. 1853. The Humorous Speaker: Being a Choice Collection of Amusing Pieces Both in Prose and Verse. New York: Newman and Ivison.

Paris, Gaston. 1903. Mediaeval French Literature, trans. Hannah Lynch. London: Dent.

Patterson, Lee. 1991. Chaucer and the Subject of History. Madison: University of Wisconsin Press.

_ 1992. Feminine Rhetoric and the Politics of Subjectivity: "La Vielle" and the "Wife of Bath." In Rethinking the Romance of the Rose: Text, Image, Reception, ed. Sylvia Huot and Kevin Brownlee, pp. 316-58. University Park: Pennsylvania State University Press. 
Perez, Gilberto. 2000. The Material Ghost: Films and Their Medium. Baltimore, MD: Johns Hopkins University Press.

Picot, Émile. 1886. Le monologue dramatique dans lancien théâtre français. Romania 15:358-422.

Pleij, Herman. 1979. Het gilde van de Blauwe Schuit. Amsterdam: Meulenhoff.

1985. Van schelmen en schavuiten. Amsterdam: Querido.

2001. Dreaming of Cockaigne, trans. Diane Webb. New York: Columbia University Press.

Revah, I. S. 1949. Les Sermons de Gil Vicente. En marge d'un opuscule du professeur Joaquim de Carvalho. Lisbon: Ottosgrafica.

Rozik, Eli. 2002. The Roots of Theatre: Rethinking Ritual and Other Theories of Origin. Iowa City: University of lowa Press.

Russell, lan. 1991. "My Dear, Dear Friends": The Parodic Sermon in Oral Tradition. In Spoken in Jest, ed. Gillian Bennett, pp. 237-56. Sheffield, England: Sheffield Academic Press.

Scribner, Robert W. 1987. Popular Culture and Popular Movements in Reformation Germany. London: Hambledon.

Stubbes, Philip. 1882. Anatomy of Abuses in England in Shakspere's Youth, ed. Frederick J. Furnivall. 2 vols. London: N. Trübner.

Thomas, P. W. 1969. Sir John Berkenhead, 1617-1679: A Royalist Career in Politics and Polemics. Oxford: Clarendon Press.

van Kampen, Hinke, Herman Pleij, Bob Stumpel, Annebel Venmans, and Paul Vriesema, eds. 1980. Het zal koud zijn in 't water als 't vriest. Zestiende-eeuwse parodieën op gedrukte jaarvoorspellingen tekstuitg. Den Haag, the Netherlands: Martinus Nijhoff.

West, James L., ed. 1978. Gyascutus: Studies in Antebellum Southern Humorous and Sporting Writing. Amsterdam: Rodopi.

Whiting, Barlett I., and Helen W. Whiting. 1968. Proverbs, Sentences, and Proverbial Phrases from English Writings, Mainly Before 1500. Cambridge, MA: Harvard University Press. 